\title{
Some Observations on the Cytochemistry of Streptomyces
}

\author{
By G. GIOLITTI \\ Antibiotics Research Laboratory, S.A. Montecatini, Milan, Italy
}

(Received 12 January 1960)

\section{SUMMARY}

Tests for the distribution of sulphydryl groups, alkaline phosphatase, catalase, peroxidase in six species of Streptomyces showed that these occurred in greatest concentration in the young aerial mycelium, and especially at its points of origin or differentiation from the vegetative mycelium. In some species, these points of differentiation took the form of synnemata (coremia) of a distinctive appearance.

\section{INTRODUCTION}

Although a considerable amount of work has been done on the subject (e.g. von Plotho, 1940 $a$, $b$; Klieneberger-Nobel, 1947; Erikson, 1947, 1949; Carvajal, 1946, 1947; Gottlieb, 1953; Pénau, Hagemann, Vèlu \& Peyré, 1954; Hagedorn, 1955; Romano \& Nickerson, 1956; Romano \& Sohler, 1956; Sohler, Romano \& Nickerson, 1958) our knowledge of the cytology and cytochemistry of actinomycetes is very incomplete. However, considerable differences have been detected between the composition of the primary and secondary mycelia of Streptomyces. It is the purpose of this paper to extend this information in respect of the distribution of sulphydryl groups and of certain enzymes which can be detected with accuracy.

\section{METHODS}

Six different strains, all from the collection maintained in this Laboratory, were used: Streptomyces griseus, S. rimosus, S. aureofaciens, S. chrysomallus, two unnamed strains, $S .829$ and $S$. 1594, both of which apparently belong to the same species (but with some different morphological characters) and produce flavensomycin.

Cultures were made on slopes of a medium containing ( $\%, w / v): 0 \cdot 1$, asparagin; 1.0, glycerol; $0 \cdot 1, \mathrm{~K}_{2} \mathrm{HPO}_{4} ; 1 \cdot \mathbf{1}$, agar; $\mathrm{pH} 7 \cdot 2-7 \cdot 4$. After incubation for 20 days at $27^{\circ}$ the spores were used to inoculate strips of sterile cellophan $(1.5 \times 3 \mathrm{~cm}$.) supported on the surface of plates of the same medium in Petri dishes. Inoculations were made sparsely, so as to produce separate colonies. After periods of $48 \mathrm{hr}$., $72 \mathrm{hr}$. and 10 days at $27^{\circ}$, strips were removed and attached to slides with a little gelatin, for cytochemical examination.

Sulphydryl groups were detected by means of the nitroprusside test of Di Mattei \& Dulzetto (1928) and by the method of Chèvremont \& Fredericq (1943). The colour given by the first test is transient, while that of the second is permanent; it is conducted on material fixed in absolute ethanol or in $20 \%(w / v)$ trichloroacetic acid. The latter reagent enhances the intensity of the reaction.

Peroxidase was detected by the method of Spirito (1934), with unfixed films 
and others treated with absolute ethanol for $20 \mathrm{~min}$. The 'leuco-zinc' method did not give positive results. Alkaline phosphatase was detected by the method of Gomori (1952), with films fixed either in acetone at $4^{\circ}$ for $24 \mathrm{hr}$., or in absolute ethanol at room temperature for $20 \mathrm{~min}$.

Controls were heated to $100^{\circ}$ for $10 \mathrm{~min}$. or were incubated without the substrate. Both types of control were used.

Catalase was detected by adding a few drops of ' 10 vol.' hydrogen peroxide, and observing the result under the microscope. The further addition of a few drops of ethanol was sometimes an improvement (see below).

The purpose of using alternative methods of fixation, and in some instances of staining, was as a control, in case of artifacts caused by the fixation or staining processes themselves.

\section{RESULTS}

In making these observations, we also observed very clearly a morphological character which seems to have been described previously only by Krassilnikov (1938). With certain strains of Streptomyces, and only on some media (asparagin glycerol agar for example) the initiation of the aerial mycelium began with the appearance of bundles of hyphae arising from the vegetative mycelium and adhering at the distal ends (Pl. 1, figs. 2, 5), which Krassilnikov designated coremia, although they seem better described as synnemata. These covered the surface of the colony; from their apices the sporogenous hyphae grew outwards (Pl. 1, fig. 3). These were clearly visible even in fresh preparations. With increase of the age of the culture, this appearance vanished and the customary form of the aerial mycelium superseded it. In the present case, these synnemata were produced by all strains examined, except Streptomyces griseus and $S$. rimosus.

Sulphydryl groups. At $48 \mathrm{hr}$. in every case the vegetative mycelium gave a very weak reaction, and the aerial mycelium, especially at its points of origin, whether or not these appeared in the form of synnemata, a much stronger one. After 10 days, the older parts of the aerial mycelium reacted less strongly in most cases, but the younger peripheral hyphae maintained their reactivity. In the case of Streptomyces aureofaciens, the whole aerial mycelium continued to react strongly after 10 days (Pl. 1, figs. 1, 2 and 6 ).

Alkaline phosphatase. After $72 \mathrm{hr}$. and 10 days the vegetative mycelium gave a weak reaction, and the aerial mycelium a strong one, especially where synnemata were visible (Pl. 1, fig. 3).

Catalase. In all strains examined, bubbles of gas first appeared at the edges of the vegetative mycelium. However, the addition of a few drops of $95 \%(\mathrm{v} / \mathrm{v})$ ethanol in water to the solution caused immediately a much stronger reaction all over the aerial mycelium. The effect was similar at $48 \mathrm{hr}$. and 10 days, and was presumably due to the production, by means of the ethanol, of a more intimate contact between the reagent and the lipid-containing surface of the aerial hyphae, which was normally hydrophobic.

Peroxidase. The vegetative mycelium at all stages produced a very slight reaction. The aerial mycelium reacted strongly at $72 \mathrm{hr}$; ; at 10 days, only the young hyphae did so. Areas with synnemata reacted especially strongly, those with mature spores weakly or negatively (Pl. 1, figs. 4, 5). 


\section{DISCUSSION}

The results show that the aerial mycelium of Streptomyces, especially when young, possesses high concentrations of sulphydryl groups, alkaline phosphatase, catalase and peroxidase. Similar results were obtained with all strains examined. The differences in reaction as between vegetative and aerial mycelium were clearly marked, except in the case of catalase, where the nature of the reaction rendered it less readily attributable to a specific location. However, even in this case, and especially after the addition of ethanol, the difference between the rate of gas production at the centre and that at the edges of the colony was striking enough to suggest that this enzyme also was in much higher concentration in the aerial mycelium as compared with the vegetative mycelium. The exception to the generally weak or negative reaction of the vegetative mycelium to the above reagents was in the growing tips, from which the aerial mycelium was beginning to differentiate. From these results and from those of other workers (e.g. Craveri, Ferrari \& Treccani, 1958) it would appear that the greatest metabolic activity is located in the aerial mycelium, and that the vegetative mycelium serves as a support and as a connexion with the culture medium.

So far as the validity of these tests is concerned, the two methods for detecting sulphydryl groups gave the same results. Peroxidase was detectable only by the benzidine method; we believe that the negative results with the 'leuco-zinc' methods were due to their specificity being for haemoglobins rather than for true peroxidases. The controls used for the alkaline phosphatase reaction give reasonable security for its specificity; the heated slides were negative, and those incubated without the specific substrate gave a very weak reaction, attributable to traces of substrate in the culture.

The interesting morphological appearance of synnemata was observable by direct examination and may be influenced by the conditions of growth and by the nature of the substrate; it was, nevertheless, shown only by certain strains, and may accordingly be of value as a taxonomic character.

\section{REFERENCES}

Carvajat, F. (1946). Studies on the structure of S. griseus. Mycologia, 38, 587.

Carvajal, F. (1947). The production of spores in submerged cultures by some Streptomyces. Mycologia, 39, 426.

Chèvremont, M. \& Frederica, J. (1943). Act. Biol. belg. 3, 62. Quoted by L. Lison, Histochimie et cytochimie animales, 2nd ed., p. 237. Paris: Gautiers and Villars, 1953.

Craveri, R., Ferrari, A. \& Treccani, V. (1958). Morfologia e studio biologico di uno Streptomyces. Ann. Microbiol. 8, 9.

Di MAtrei, P. \& Dulzetro, F. (1928). Un metodo di dosaggio del glutatione. R.C. Accad. Lincei, 8, 317.

Erikson, D. (1947). Differentiation of the vegetative and sporogenous phases of the Actinomycetes. J. gen. Microbiol. 1, 39.

Erikson, D. (1949). The morphology, cytology, and taxonomy of the Actinomycetes. Annu. Rev. Microbiol. 3, 28.

GomorI, G. (1952). Microscopic Histochemistry, p. 184. University of Chicago Press.

Gotrutes, D. (1953). The physiology of the actinomycetes. 6th Congr. int. Microbiol., p. 122. Symposium Actinomycetales.

Hagedorn, H. (1955). Beiträge zur Cytologie und Morphologie der Actinomyceten. Z Zbl. Bact. (II Abt.), 108, 353. 
KuIENEBERGER-Nobex, E. (1947). The life cycle of sporing Actinomyces as revealed by a study of their structure and septation. J. gen. Microbiol. $1,22$.

Krassilnikov, N. A. (1938). Manual of the Ray Fungi. Moscow: Acad. Nauk.

Pénau, H., Hagemann, G., Vèlu, H. \& Pexré, M. (1954). Modalités du cycle évolutif de $S$. griseus en culture profonde. Rev. Immunol. 18, 265.

Plotro, von, O. (1940a). Beiträge zur Kenntnis der Morphologie und Physiologie der Actinomyceten. Arch. Mikrobiol. 11, 33.

Plotho, von, O. (1940b). Die chromatische Substanz bei Actinomyceten. Arch. Mikrobiol. 11, 285.

Romano, A. M. \& Nickerson, W. J. (1956). The biochemistry of the Actinomycetales. I. Studies on the cell-wall of $S$. fradiae. J. Bact. 72, 478.

Romano, A. M. \& Sohler, A. (1956). Biochemistry of the Actinomycetales. II. A comparison of the cell-wall composition of species of the genera Streptomyces and Nocardia. J. Bact. 72, 865.

Sohler, A., Romano, A. M. \& Nickerson, W. J. (1958). Biochemistry of the Actinomycetales. III. Cell-wall composition and the action of lysozyme upon cells and cell walls of the actinomycetales. J. Bact. 75, 283.

Spirito, A. (1934). Ricerche sul comportamento dei fermenti embrionali. I. Le perossidasi nei Ciclostomi, Pesci, Anfibi. Arch. Sci. biol., Napoli, 20, 442.

\section{EXPLANATION OF PLATE 1}

Fig. 1. Streptomyces griseus; $48 \mathrm{hr}$. growth; sulphydryl reaction. Magnification, $\times 200$.

Fig. 2. Streptomyces no. $829 ; 48 \mathrm{hr}$. growth; sulphydryl reaction. Note the intensity of the reaction of the synnemata. Magnification, $\times 200$.

Fig. 3. As fig. $2 ; 72$ hr. growth; alkaline phosphatase reaction. Note the intensity of the reaction of the synnemata. Magnification, $\times 200$.

Fig. 4. As fig. $1 ; 72 \mathrm{hr}$. growth; peroxidase reaction. Magnification, $\times 200$.

Fig. 5. As fig. 2; $72 \mathrm{hr}$. growth; peroxidase reaction. Note the form of the synnemata and the intensity of their reaction. Magnification, $\times 200$.

Fig. 6. Streptomyces aureofaciens; 10-day culture; sulphydryl reaction. Synnemata are intensely stained. Magnification, $\times 200$. 


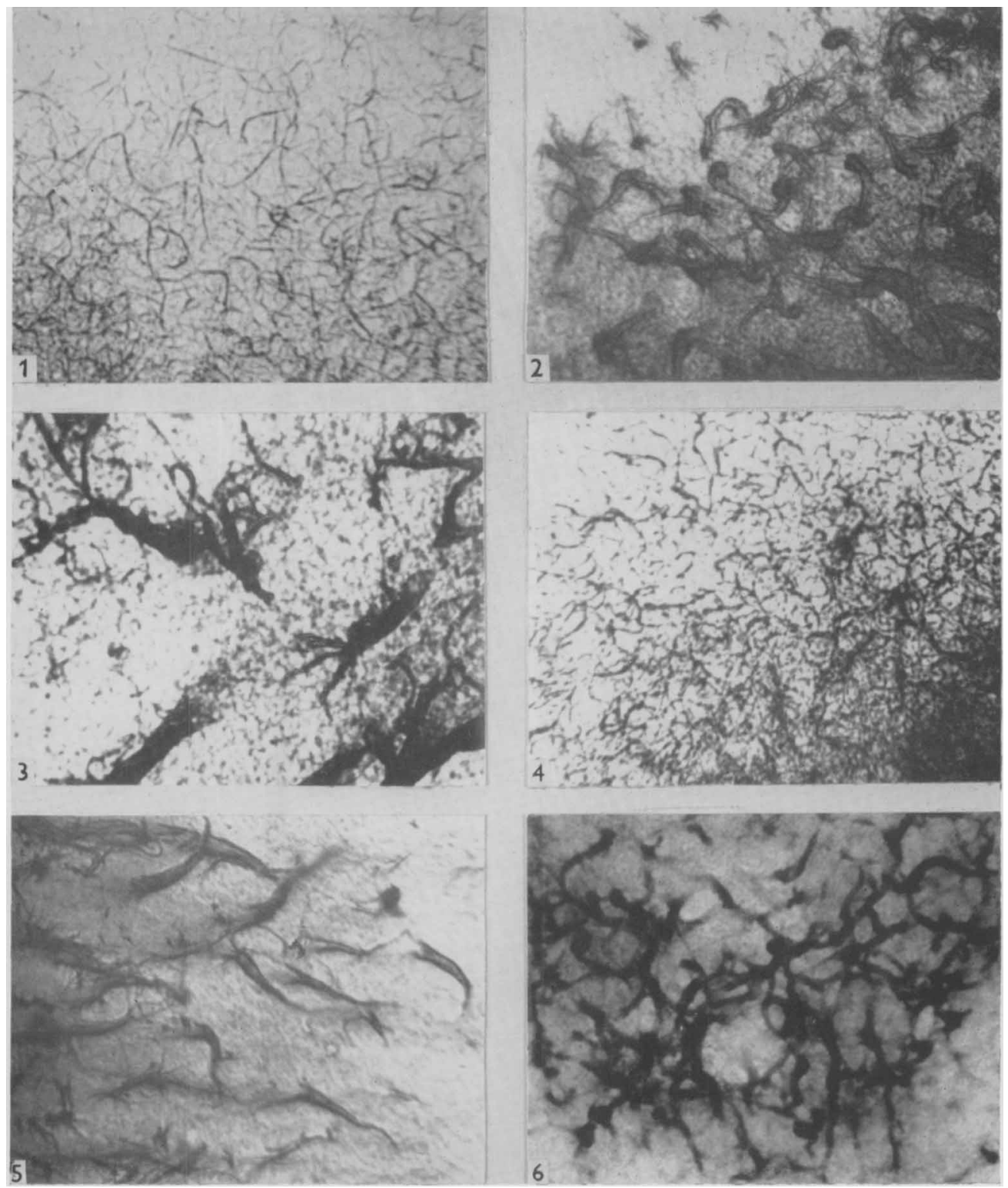

\section{G. GIOLI'T'TI}

